\title{
Deintensification of land use leads to recovery of soil microbial community composition and function after land use change in Ethiopia
}

\author{
Yoseph Delelegn ${ }^{1}$, Witoon Purahong ${ }^{2}$, Ali Nawaz ${ }^{2}$, Hans Sandén ${ }^{1}$, Douglas Godbold ${ }^{1}$, and \\ Tesfaye Wubet ${ }^{2}$ \\ ${ }^{1}$ University of Natural Resources and Life Sciences Vienna \\ ${ }^{2}$ Helmholtz Centre for Environmental Research UFZ Department of Soil Ecology
}

April 6, 2021

\begin{abstract}
Ethiopia has undergone significant land use change during the past centuries, particularly deforestation. These changes have resulted in the loss of topsoil as well as the associated soil ecosystem functions. Grazing exclusion and planting of eucalyptus are measures used to recover degraded lands and reduce deforestation, respectively. Using a gradient of the intensity of land use from natural forest to croplands, we investigated whether these measures also result in restoration of the soil microbial community. We identified the soil bacterial and fungal communities using paired-end amplicon sequencing. A total of 12,765 fungal and 12,325 bacterial OTUs were detected in the five land use types, and only ca. $2 \%$ and $17 \%$ were shared among the land uses, respectively. Total fungal and bacterial OTU richness was not significantly affected by land use change, but the conversion of forest to cropland resulted in the loss of approximately $40 \%$ and $11 \%$ of the total native fungal and bacterial OTUs, respectively. Soil pH, C, N, and aggregate stability were key factors corresponding to the overall bacterial and fungal community compositions. We also showed relationships between the microbial functional group and enzyme activities. The exclusion of grazing led to an enrichment of soil microbial communities that overlapped with the communities of the natural forest. Our results suggest that remnant native forests act as refugia for microbial communities and that restoration of microbial communities and concomitant recovery of ecosystem function via deintensification of land use is possible. Keywords: ectomycorrhiza, ericoid mycorrhiza, exclosure, microbial diversity, soil enzymes
\end{abstract}

\section{Hosted file}

Main Document_Delelegn_Final_14M2021.pdf available at https://authorea.com/users/406034/ articles/516853-deintensification-of-land-use-leads-to-recovery-of-soil-microbialcommunity-composition-and-function-after-land-use-change-in-ethiopia

\section{Hosted file}

Figure 1_Fungal Richness.pdf available at https://authorea.com/users/406034/articles/516853deintensification-of-land-use-leads-to-recovery-of-soil-microbial-community-compositionand-function-after-land-use-change-in-ethiopia

\section{Hosted file}

Figure 2_Bacterial Richness.pdf available at https://authorea.com/users/406034/articles/ 516853-deintensification-of-land-use-leads-to-recovery-of-soil-microbial-communitycomposition-and-function-after-land-use-change-in-ethiopia

\section{Hosted file}


Figure 3_Environmntal factors.pdf available at https://authorea.com/users/406034/articles/ 516853-deintensification-of-land-use-leads-to-recovery-of-soil-microbial-communitycomposition-and-function-after-land-use-change-in-ethiopia 